\title{
ANNOUNCEMENT
}

\section{UNITED NATIONS CONGRESS ON PUBLIC INTERNATIONAL LAW (NEW YORK, 13-17 MARCH 1995)}

\author{
Information note from the United Nations
}

The United Nations Congress on Public International Law, held in New York from 13-17 March 1995 on the general theme 'Towards the Twenty-First Century: International Law as a Language for International Relations', was a unique event in the history of the Organization. Never before had there been on United Nations premises such a gathering of international lawyers of all nationalities involved not in the conduct of negotiations in a conference context, but in exchanges of views on a number of issues relating to their profession.

As stressed by the Secretary-General of the United Nations, Mr. BoutrosBoutros Ghali, the event was widely recognized as a success. It proved to be a most rewarding experience for those who participated in it, those who planned for it for years, and those who where in charge of the smooth conduct of the deliberations.

The year 1995 was deliberately chosen so as to make the Congress part of the activities being undertaken to celebrate the Fiftieth Anniversary of the United Nations and also because it marked the mid-point of the United Nations Decade of International Law (1989-1999) proclaimed by General Assembly resolution 44/23 o 17 November 1989. It is, in point of fact, under the Decade Programme, that the idea of convening the congress was launched and preparatory work for it discussed. It is therefore no coincidence that four of the five topics which were chosen for the plenary meetings of the Congress were inspired by the four aims of the Decade.

The first topic, which provided the theme for the first day of the Congress, concerned 'The principles of international law: theoretical and practical aspects of their promotion and implementation'. It was introduced by the Moderator for the day, Mr. Javad Zarif, whose presentation was followed by six lectures as follows:

Hisashi Owada, 'Justice and stability in the international order'; Dumitra Popescu, 'The universality of international law: concepts and limits', Maria Teresa Infante Caffi, 'Regional and universal prospects for the establishment and effectiveness of new principles in relations between States'; Brigitte Stern, 'The evolution of the role of the United Nations in peacekeeping'; Jochen A. Frowein, 'The promotion and implementation of international law through national courts'; 
and Kari Hakapää, 'Difficulties of global negotiations: the dilemma of maritime delimitation'.

The topic selected for the second day of the congress was entitled 'Means of peaceful settlement of disputes between States, including resort to and full respect for the International Court of Justice'. The moderator was Ms. Rosalyn Higgins whose presentation was followed by six lectures as follows:

Mohammed Bedjaoui, 'The resources available through the Court's advisory function: result and prospects'; Santiago Torres Bernárdez, 'The function of the International court of Justice in the system established under the Charter of the United Nations'; B.S. Murthy, 'Diplomacy and resolution of international disputes'; Oleg Khlestov, 'Enhancing the role of regional arrangements or agencies in the peaceful settlement of disputes'; Miguel Angel González Félix, 'Development and current trends in international law with regard to the peaceful settlement of disputes'; and Achol Deng, 'The peacefulmanagement of transboundary natural resources'.

The topic of the third day was entitled 'Conceptual and practical aspects of the codification and progressive development of international law: new developments and priorities'. The moderator was Mr. Emilio Cárdenas whose presentation was followed by seven lecturers as follows:

Eric Suy, 'Progressive development and codification of international law: the role of the General Assembly revisited'; Karl Zemanek, 'Does codification lead to wider acceptance?'; Alexander Yankov, 'Strengthening the process of codification and progressive development of international law: the evolving functions of the International Law Commission and increasing the commitment of States'; Christopher Pinto, 'Democratization of international relations and its implications for the development and application of international law'; Vicente Marotta Rangel, 'Codification of the law of the sea: prospects for new developments'; and Edith Brown Weiss, 'New directions in international environmental law'.

The topic for the fourth day read 'New approaches to research, education and training in the field of international law and its wider appreciation'. The moderator was Mr. Edward Arthur Laing whose presentation was followed by six lecturers as follows:

Mohamed Bennani, 'The promotion of international law through research and new teaching methods'; Wang Tieya, 'Universal approach to the teaching of international law'; Héctor Gros Espiell, 'The teaching of international law and recent changes in international realities: continuity and modernization'; Luigi $L$. Ferrari-Bravo, 'Training and education machinery in the field of international law'; Zdzislaw Galicki, 'Traditional and new fields for the development of research and education in international law'; and Donald Buckingham, 'Creating world-class citizens: international law as an essential ingredient in secondary school education'. 
Finally, the fifth day of the Congress was devoted to the theme 'Towards the Twenty-first Century: New Challenges and Expectations'. The moderator was Mr. Danilo Türk whose introduction was followed by five lectures as follows:

Chi Young Pak, 'The changing role of international law in world society'; Sir Ninian Stephen, 'Meeting expectations through process and practice'; Louis Sohn, 'Making international law more user-friendly'; Olexander Chaly, 'Problems of succession in contemporary international law'; and Peter Maynard, 'Universality and the United Nations'.

Apart from the above plenary discussions, several round tables were also organized by participants or groups of participants on a variety of specific issues.

This brief note cannot attempt to analyse or assess the presentations made nor the exchanges of views to which they gave rise in the framework of the open floor discussions which took place at each meeting. Its modest goal is to keep the affairs of the Congress alive in the minds of the international community.

The proceedings of the Congress, including, inter alia, the opening statement by the Legal Counsel of the United Nations, the above presentations made at the plenary meetings and the summaries of round-table discussions as well as the concluding address of the Secretary-General will be compiled in a United Nations publication to be issued in the near future.

\author{
Hans Corell \\ UN Under-Secretary-General \\ for Legal Affairs
}

